\title{
PENGECUALIAN PERJANJIAN HAK KEKAYAAN INTELEKTUAL DALAM HUKUM PERSAINGAN USAHA
}

\section{Exclusion of Intellectual Property Rights Agreement in the business Competition Law}

\author{
Dani Amran Hakim \\ Universitas Diponegoro, Semarang \\ email: daniamranhakim@yahoo.com
}

\begin{abstract}
Law business competition in the country Indonesia know the exceptions to assert that a the rule of law expressed does not apply for those kind certain agents or behavior particular activity. Law competition business environment in general grant an exemption on the basis of agreement, for example agreement intellectual property rights (IPR). IPR is incentives and reason was given the right monopolizes and protection because IPR need resources and time in an effort to get it, based on article 50 alphabet b Law on Business Competition. An exemption based on article 50 alphabet b Law on Business Competition the elaborated competition supervisory commission by issuing commission rules business competition supervisory Law Number 2 of 2009 on Exceptions The Application of the Law Number 5 of 1999 on Prohibition of Monopoly and Unfair Business Competition of a Pertaining to Intellectual Property Rights Scope arrangement based on Commission Rules Business Competition Supervisory Number 2 of 2009 is: (1) the license agreement that is in scope patent, the right brand, copyright, the right industrial design, the right design the layout integrated circuit and the right trade. (2) Trademark and brand services. (3) the design layout integrated circuit.
\end{abstract}

Keywords: Exeptions, Intellectal Property Rights, Business Competition Law

\begin{abstract}
abstrak
Hukum persaingan usaha di negara Indonesia mengenal adanya pengecualian (exemption) untuk menegaskan bahwa suatu aturan hukum dinyatakan tidak berlaku bagi jenis pelaku tertentu ataupun perilaku/kegiatan tertentu. Hukum persaingan usaha pada umumnya memberikan pengecualian atas dasar perjanjian, misalnya perjanjian hak kekayaan intelektual (HKI). HKI merupakan insentif dan alasan diberikan hak memonopoli dan proteksi karena HKI membutuhkan sumber daya dan waktu dalam upaya mendapatkannya, berdasarkan Pasal 50 huruf b UU Persaingan Usaha.
\end{abstract}


Pengecualian berdasarkan Pasal 50 huruf b UU Persaingan Usaha tersebut dijabarkan Komisi Pengawas Persaingan Usaha (KPPU) dengan mengeluarkan Peraturan Komisi Pengawas Persaingan Usaha Nomor 2 Tahun 2009 tentang Pengecualian Penerapan UU No. 5 Tahun 1999 tentang Larangan Praktek Monopoli dan Persaingan Usaha Tidak Sehat Terhadap Perjanjian yang Berkaitan Dengan Hak Atas Kekayaan Intelektual Ruang lingkup pengaturan berdasarkan PerKom Nomor 2 Tahun 2009 adalah: (1) perjanjian lisensi yang berada dalam lingkup hak paten, hak merek, hak cipta, hak desain industri, hak desain tata letak sirkuit terpadu, dan hak rahasia dagang. (2) merek dagang dan merek jasa. (3) desain tata letak sirkuit terpadu.

Kata Kunci: Pengecualian, Hak Atas Kekayaan Intelektual, Hukum Persaingan Usaha

\section{A. Pendahuluan}

Perkembangan di dalam aktivitas ekonomi saat ini, setiap individu, lembaga atau perusahaan tentunya memiliki target bisnis masing-masing untuk mendapatkan keuntungan, sehingga berbagai upaya dilakukan dengan mengelaborasikan sumber daya yang dimiliki untuk meraih kepuasan maksimal. Karena hal itu, maka munculah istilah persaingan usaha di antara mereka dalam menjalankan aktifitas ekonominya. Salah satu masalah yang dihadapi oleh perusahaan dan dunia usaha pada umumnya adalah adanya persaingan. ${ }^{1}$

Berbagai kegiatan ekonomi atau aktivitas bisnis dapat dipastikan terjadinya persaingan (competition) di antara pelaku usaha. Pelaku usaha akan berusaha menciptakan, mengemas, serta memasarkan produk yang dimiliki baik barang/jasa sebaik mungkin agar diminati dan dibeli oleh konsumen. Persaingan dalam usaha dapat berimplikasi positif, sebaliknya, dapat menjadi negatif jika dijalankan dengan perilaku negatif dan menyebabkan tidak kompetitifnya kegiatan ekonomi. ${ }^{2}$

Berdasarkan Pasal 33 Undang-Undang Dasar Negara Republik Indonesia Tahun 1945 menyatakan bahwa sistem ekonomi yang dianut

\footnotetext{
${ }^{1}$ Sukanto Reksohadiprodjo dan Indriyo Gito Sudarmo, Managemen Produksi, (Yogyakarta: BPFE UGM, 1988), hlm. 57.

${ }^{2}$ Pada hakikatnya kegiatan ekonomi adalah kegiatan menjalankan perusahaan, yaitu suatu kegiatan yang mengandung pengertian bahwa kegiatan yang dimaksud harus dilakukan dengan beberapa cara yaitu: a) secara terus-menerus dan tidak terputus atau suatu kegiatan yang berkelanjutan; b) secara terang-terangan sah (bukan ilegal) sesuai dengan ketentuan peraturan yang berlaku; c) kegiatan tersebut dilakukan dalam rangka memperoleh keuntungan untuk diri sendiri dan orang lain. Lihat Sri Redjeki Hatono, Hukum Ekonomi Indonesia, (Malang: Bayumedia, 2007), hlm. 40.
} 
negara adalah ekonomi kerakyatan atau demokrasi ekonomi yang bertujuan untuk mewujudkan kesejahteraan dan keadilan sosial sebagai cita-cita pembangunan ekonomi. Korelasi yang muncul kemudian dalam menyusun kebijakan perekonomian negara harus senantiasa berusaha menghilangkan ciri-ciri negatif yang terkandung dalam sistem ekonomi liberal dan sistem ekonomi sosialisme, yaitu free fight liberalism yang membenarkan eksploitasi terhadap manusia, etatisme di mana negara beserta aparaturnya meminimumkan potensi dan daya kreasi unit ekonomi di luar sektor negara, dan pemusatan ekonomi pada salah satu kelompok yang bersifat monopoli yang merugikan masyarakat. ${ }^{3}$

Kekuatan ekonomi yang kokoh merupakan landasan utama suatu negara di belahan dunia manapun, apabila suatu negara atau bangsa memiliki tingkat atau ekonomi yang kuat berarti negara tersebut memiliki kedaulatan yang sejajar dengan negara lain. Untuk menuju ketatanan negara yang berdaulat secara ekonomi, maka diperlukan kesinergisan antara pemerintah dan masyarakat dalam membangun political will tentang pengelolaan ekonomi. Negara merupakan pihak yang memiliki kewenangan dalam meletakkan dasar-dasar aturan yang mendukung dan dapat melindungi pertumbuhan serta aktifitas kegiatan ekonomi. ${ }^{4}$

Dunia bisnis di Indonesia saat ini berkembang tanpa batas sehingga mampu menerobos dimensi kehidupan dan perilaku perekonomian manusia. ${ }^{5}$ Adanya persaingan dalam dunia bisnis memberikan manfaat yang tidak sedikit bagi kehidupan, namun untuk menghindari sisi negatif dari persaingan, perlu dibuat aturan yang jelas, sehingga persaingan dapat berjalan dengan baik atau dengan kata lain tercipta suatu level playing field, yang membuat pelaku-pelaku usaha kecil tetap dapat menjalankan usaha di samping pelaku-pelaku usaha besar tetap dapat menjalankan usahanya. ${ }^{6}$

Perkembangannya kemudian munculah Undang-Undang Nomor 5 Tahun 1999 tentang Larangan Praktik Monopoli dan Persaingan Usaha Tidak Sehat (UU Persaingan Usaha) sebagai instrumen kelengkapan hukum yang mendorong terciptanya efisiensi ekonomi dan iklim kesempatan berusaha yang sama bagi pelaku usaha. Selain itu juga sebagai rambu-rambu untuk memagari agar tidak terjadi praktik-praktik ekonomi yang tidak sehat

\footnotetext{
${ }^{3}$ Ahmad Yani dan Gunawan Widjaja, , Seri Hukum Bisnis Anti Monopoli, (Jakarta: Rajawali Pers, 1999), hlm. 4.

4 Abdullah Abdul Husain At-Tariqi, Ekonomi Islam: Prinsip Dasar dan Tujuan, (Yogyakarta: Magistra Insani Press, 2004), hlm. 275.

5 A. Rahmad Rosyadi dan Ngatino, Arbitrase Islam dalam Perspektif Islam dan Hukum Positif, (Bandung: PT. Citra Aditya Bakti, 2000), hlm. 1.

${ }^{6}$ Ditha Wiradiputra, "Hukum Persaingan Usaha Di Indonesia", Modul untuk Retooling Program Under Employe Graduates at Priority Disciplines Under TSPDP, DIKTI, Jakarta 14 Desember 2004.
} 
dan tidak wajar. Undang-Undang Persaingan Usaha inilah yang kemudian juga mengatur mengenai ketentuan perjanjian-perjanjian yang dilarang.

Selain mengatur mengenai ketentuan perjanjian-perjanjian yang dilarang, hukum persaingan usaha juga mengenal adanya pengecualian (exemption) untuk menegaskan bahwa suatu aturan hukum dinyatakan tidak berlaku bagi jenis pelaku tertentu ataupun perilaku/kegiatan tertentu. Oleh sebab itu diperlukan adanya suatu acuan yang dipergunakan untuk pengecualian apakah suatu kegiatan, industri/badan, pelaku usaha yang bagaimanakah yang dikecualikan dari pengaturan hukum persaingan usaha. Pemberian pengecualian dalam hukum persaingan usaha umumnya didasarkan pada beberapa pertimbangan, antara lain: a) Adanya instruksi atau perintah dari UUD 1945; b) Adanya instruksi atau perintah dari UU ataupun peraturan perundangan lainnya; dan c) Instruksi atau pengaturan berdasarkan regulasi suatu badan administrasi. ${ }^{7}$

Ketentuan pengecualian terhadap perjanjian dalam hukum persaingan usaha berkaitan dengan hak atas kekayaan intelektual (HKI) seperti lisensi, paten, merek dagang, hak cipta, desain produk industri, rangkaian elektronik terpadu, dan rahasia dagang. Pasal 50 huruf b UU Persaingan Usaha mengecualikan perjanjian yang berkaitan dengan hak atas kekayaan intelektual seperti lisensi, paten, merek dagang, hak cipta, desain produk industri, rangkaian elektronik terpadu, dan rahasia dagang, serta perjanjian yang berkaitan dengan waralaba.

Berdasarkan uraian di atas penulis tertarik untuk mengaji mengenai pengaturan pengecualian perjanjian hak kekayaan intelektual dalam hukum persaingan usaha dengan rumusan masalah sebagai berikut: 1) Bagaimanakah hubungan antara hukum hak kekayaan intelektual dan hukum persaingan usaha?; 2) Bagaimanakah pengaturan pengecualian perjanjian hak kekayaan intelektual dalam hukum persaingan usaha?

\section{B. Pembahasan}

\section{Pengecualian Dalam Hukum Persaingan Usaha}

Persaingan dalam mekanisme pasar adalah berlaku bagi setiap pelaku pasar tanpa terkecuali. Hukum persaingan usaha melindungi mekanisme proses persaingan tanpa mempertimbangkan siapakah yang menjadi pelakunya dengan tujuan yang baik agar alokasi sumber daya menjadi efisien. Mekanisme pasar yang berjalan melalui persaingan yang sehat dan fair serta konsisten dengan tujuan distribusi yang adil diharapkan mampu

7 Andi Fahmi Lubis, dkk., Hukum Persaingan Usaha Antara Teks dan Konteks, (Jakarta: ROV Creative Media, 2009), hlm. 218, Lihat juga Thomas Jorde, et all., Gilbert Law Summaries-Antitrust, 9th ed., (Harcourt Brace Legal and Professional Publications. Inc, 1996), hlm. 114. 
mencapai efisiensi nasional serta kesejahteraan umum. Di samping itu hukum persaingan usaha diharapkan mampu mengawasi terjadinya diskriminasi harga, pemerataan informasi pasar bagi yang kurang mampu mempunyai akses, kesempatan atau akses kepada modal, teknologi dan berbagai kesempatan berusaha lainnya. Tetapi bila berbagai tujuan yang baik untuk mendukung mekanisme pasar ini tidak berhasil dicapai, maka dapat berakibat pada kegagalan mekanisme pasar yang kemungkinan dilakukan oleh pelaku pasar yang bertentangan dengan prinsip persaingan usaha yang sehat.

Hukum persaingan usaha berupaya mengawasi agar perbuatan atau perjanjian yang bersifat anti persaingan seperti kartel, monopoli, penggunaan posisi dominan, monopsoni dan lainnya dapat dicegah. Tetapi pada kenyataannya ada juga berbagai kegagalan pasar yang terjadi tetapi tidak dapat dijangkau, dicegah atau diatur melalui hukum persaingan usaha. Oleh sebab itu ada kebutuhan yang mendasar terhadap pentingnya pengaturan atau regulasi yang jelas mengenai jenis tindakan atau kegiatan, industri ataupun pelaku usaha tertentu yang tidak termasuk dalam pengaturan hukum persaingan usaha. Sebagai contoh, dibutuhkan adanya regulasi terhadap industri yang masuk dalam kategori kepentingan umum (misalnya monopoli alamiah dalam penyediaan air bersih, listrik atau telekomunikasi). Di mana bila diperhitungkan secara ekonomi, maka proses produksi yang dilakukan oleh hanya satu perusahaan akan mampu mengurangi biaya produksi secara keseluruhan. Ada juga keadaan di mana akibat penggunaan sumber daya yang tidak diatur dengan baik terhadap sumber daya yang sifatnya universal akan mengakibatkan terjadinya externalities. ${ }^{8}$

Di negara yang dalam proses mengadopsi sistem ekonomi pasar ataupun sedang dalam proses transisi menuju ekonomi pasar, dirasakan adanya kepentingan pembatasan terhadap perilaku yang bertujuan mengeksploitasi pasar. Di samping itu perlu juga menciptakan mekanisme pengontrolan di industri yang secara ekonomi tidak kompetitif sehingga eksploitasi pasar dapat dihindarkan. Oleh sebab itu harus ada pengaturan terhadap kondisi yang menghambat persaingan dengan jalan mengontrol perilaku pelaku usaha, melalui regulasi yang mengatur industri apa sajakah yang dikategorikan sebagai competitive dan non-competitive, ataupun

8 Robert H. Bork, The Antitrust Paradox, A Policy at War with Itself, (New York: Basic Books Inc, 1978), hlm. 114 -155. Externalities refer to a cost that one economic actor imposes on another (or benefits that one receives from another) without paying in the market for doing so-ie: environtment waste etc. Dengan kata lain, dalam ilmu ekonomi Externalities dinyatakan sebagai biaya di mana suatu perusahaan membebaninya terhadap perusahaan lain (ataupun dapat saja berupa suatu keuntungan yang diterima oleh suatu perusahan dari perusahaan lain) tanpa ikut serta membiayainya dalam suatu pasar atau industri, misalnya: pembuangan limbah dan lain-lain. 
regulasi yang jelas mengenai industri yang diproteksi atau dikecualikan dari pengaturan undang-undang. Keseluruhan ini sangat ditentukan oleh kebijakan persaingan serta peraturan pelaksananya. ${ }^{9}$

Keputusan untuk memberlakukan regulasi juga dipengaruhi oleh berbagai faktor misalnya kepentingan sosial, politik dan kondisi perekonomian suatu negara. Oleh sebab itu bentuk, tujuan, karakter dan ruang lingkup pengaturan tersebut dapat saja berubah sesuai kondisi yang ada pada saat itu. Sebagai contoh, selama beberapa dekade pasar di Indonesia sangat dipengaruhi oleh pemberian hak khusus kepada sekelompok pengusaha tertentu dan demikian juga pada saat yang bersamaan pemerintah mempunyai kebijakan untuk memroteksi usaha kecil dan menengah yang didasarkan pada interpretasi Pasal 33 UUD Tahun 1945. Kebijakan ini melahirkan konglomerasi ataupun pada kesempatan lain menciptakan mekanisme bapak angkat untuk koperasi dan UKM. Sesudah terjadinya krisis ekonomi pada tahun 1998, terjadi perubahan yang cukup signifikan saat pemerintah melakukan deregulasi di berbagai bidang. Berbagai faktor kegagalan perekonomian saat itu dianggap berasal dari ketidakjelasan kebijakan persaingan yang diterapkan oleh pemerintah sehingga mendorong kebutuhan lahirnya Undang-Undang Anti Monopoli beserta peraturan lainnya. ${ }^{10}$

Pada umumnya kebijakan persaingan dipengaruhi oleh berbagai pertimbangan misalnya: adanya perlindungan terhadap hak kekayaan intelektual (HKI), perdagangan, perlindungan terhadap usaha kecil atau menengah serta kepentingan nasional terhadap perekonomian yang dikelola oleh Badan Usaha Milik Negara (BUMN). Hukum persaingan usaha juga mengenal adanya pengecualian (exemption) untuk menegaskan bahwa suatu aturan hukum dinyatakan tidak berlaku bagi jenis pelaku tertentu ataupun perilaku/kegiatan tertentu. Untuk itu perlu kita mengetahui alasan apakah yang menjadi dasar pertimbangan diberikannya pengecualian dalam undangundang hukum persaingan usaha. Pada umumnya pengecualian yang diberikan berdasarkan 2 alasan, yaitu:

a) industri atau badan yang dikecualikan telah diatur oleh peraturan perundang-undangan atau diregulasi badan pemerintah yang lain dengan tujuan memberikan perlindungan khusus berdasarkan kepentingan umum (public interests), misalnya: transportasi, air minum, listrik, telekomunikasi, dan lain-lain; dan

b) suatu industri memang membutuhkan adanya perlindungan khusus karena praktek kartel tidak dapat lagi dihindarkan dan dengan pertimbangan ini

\footnotetext{
${ }^{9}$ Corwin D. Edwards, Maintaining Competition Requisites of a Governmental Policy, 1 st ed, (McGraw Hill Book Company, Inc, 1949), hlm. 14-15.

${ }^{10}$ Lihat pendapat Prof. Sadli dalam Hall Hill, The Indonesian Economy Since 1966, 2nd ed. (Cambridge University Press, 2000) hlm. 93.
} 
maka akan jauh lebih baik memberikan proteksi yang jelas kepada suatu pihak daripada menegakkan undang-undang hukum persaingan usaha itu sendiri. ${ }^{11}$

Berdasarkan pertimbangan dan alasan ini maka pada umumnya berbagai negara memberikan atau mengatur tentang pengecualian di dalam undang-undang hukum persaingan usaha mereka. Dengan kata lain, pengecualian merupakan hal yang umum dalam undang-undang hukum persaingan usaha dan tidak dianggap sebagai hal yang dirasa dapat menghambat persaingan usaha itu sendiri. ${ }^{12}$

Pengecualian dalam hukum persaingan usaha dapat diberikan dengan alasan proteksi kepada suatu industri atau pelaku usaha tertentu yang dianggap masih memerlukan perlindungan. Pemerintah merasa perlu memberikan proteksi dengan alasan industri ini belum mampu menghadapi persaingan yang disebabkan faktor, misalnya keterbatasan modal, belum mampu efisien, kendala distribusi, kurang inovatif sehingga tidak akan mampu bertahan di pasar. Jenis pelaku usaha yang masuk dalam kategori seperti ini adalah koperasi dan usaha kecil dan menengah yang masuk dalam usaha industri kecil rumah tangga dalam skala sederhana. Sedangkan pemberian proteksi terhadap jenis pelaku usaha tertentu pada umumnya bukan saja diberikan berdasarkan kemampuan, tetapi juga dengan melihat jumlah mereka dalam perekonomian nasional apakah jumlahnya signifikan atau mayoritas dalam suatu pasar atau tidak. ${ }^{13}$

Di samping itu undang-undang hukum persaingan usaha pada umumnya memberikan pengecualian atas dasar perjanjian, misalnya perjanjian Hak Kekayaan Intelektual (HKI). HKI merupakan insentif dan alasan diberikan hak memonopoli dan proteksi karena HKI membutuhkan sumber daya dan waktu dalam upaya mendapatkannya. Undang-Undang HKI sendiri menjamin bahwa penemuan paten dan lain-lain akan diberikan perlindungan sebelum dapat menjadi milik publik (public domain). Faktor ini menjadi penentu bagi perusahaan karena insentif ini dianggap sebagai jalan menguasai pasar tetapi tidak merupakan pelanggaran undang-undang. ${ }^{14}$

11 Thomas Jorde, Op Cit, hlm. 114.

12 Sebagai contoh, Amerika Serikat memberlakukan pengecualian terhadap Perjanjian Perburuhan (labor exemption) dan Industri Asuransi (insurance exemption) dengan mengeluarkan McCarran-Fergusson Act, di samping pengecualian lain terhadap pertanian dan perikanan, usaha kecil dan menengah, asosiasi ekspor dan olahraga dan lainnya. Sementara Jepang terfokus pada pengecualian terhadap pertanian dan koperasi.

13 Lihat Roderick Brazier dan Sahala Sianipar, eds., "Undang-Undang Antimonopoli Indonesia dan Dampaknya Terhadap Usaha Kecil dan Menengah" The Asia Foundation

${ }^{14}$ L. A. Sullivan, 1977, Antitrust. (Co. Minnesota: West Publishing, 1999), hlm. 801. 


\section{Hubungan Antara Hukum Hak Kekayaan Intelektual dan Hukum Persaingan Usaha}

Hukum persaingan usaha adalah elemen esensial sehingga dibutuhkan adanya undang-undang sebagai "code of conduct" bagi pelaku usaha untuk bersaing di pasar sesuai dengan aturan undang-undang. Negara berkepentingan bahwa kebijakan persaingan adalah ditujukan untuk menjaga kelangsungan proses kebebasan bersaing itu sendiri yang diselaraskan dengan freedom of trade (kebebasan berusaha), freedom of choice (kebebasan untuk memilih) dan access to market (terobosan memasuki pasar). ${ }^{15}$ Undang-Undang No. 5 Tahun 1999 (UU Persaingan Usaha) juga bertujuan untuk meningkatkan efisiensi nasional melalui pengalokasian sumber daya dengan berlandaskan demokrasi ekonomi dengan memperhatikan keseimbangan antara kepentingan pelaku usaha dan kepentingan umum. ${ }^{16}$

Di samping tujuan tersebut, secara eksplisit UU Persaingan Usaha juga menegaskan bahwa ada kebijakan persaingan yang berorientasi pada jaminan kesempatan berusaha yang sama bagi pelaku usaha besar, pelaku usaha menengah dan pelaku usaha kecil. Oleh sebab itu kebijakan persaingan (competition policy) ${ }^{17}$ suatu negara dalam penegakan hukum persaingan akan sangat menentukan efektif berlakunya undang-undang hukum persaingan usaha. Kebijakan ini diterjemahkan dengan mempertimbangkan industri manakah yang perlu diregulasi atau industri manakah yang terbuka untuk bersaing.

Hukum Persaingan Usaha di Negara Indonesia mengenal adanya pengecualian (exemption) untuk menegaskan bahwa suatu aturan hukum dinyatakan tidak berlaku bagi jenis pelaku tertentu ataupun perilaku/kegiatan tertentu. Oleh sebab itu diperlukan adanya suatu acuan yang dipergunakan untuk pengecualian apakah suatu kegiatan, industri/badan, pelaku usaha yang bagaimanakah yang dikecualikan dari pengaturan hukum persaingan. ${ }^{18}$ Berdasarkan Pasal 50 huruf b UU Persaingan Usaha mengecualikan perjanjian yang berkaitan dengan hak atas kekayaan intelektual seperti lisensi, paten, merek dagang, hak cipta, desain produk industri, rangkaian

\footnotetext{
${ }^{15}$ R.S. Khemani, "A Framework for the Design and Implementation of Competition Law and Policy”. (World Bank and OECD.) hlm. 4.

${ }^{16}$ Lihat Bab II Asas dan Tujuan, Pasal 2 yang mengatakan bahwa "Pelaku usaha di Indonesia dalam menjalankan kegiatan usahanya berasaskan demokrasi ekonomi dengan memperhatikan keseimbangan antara kepentingan pelaku usaha dan kepentingan umum".

${ }^{17}$ Edward M. Graham and J. David Richardson, Global Competition Policy, Institute for International Economics, (Washington DC, 1997), hlm. 23. Competition policy is concerned with the interfirm behavior as well as the behavior of each other firm alone.

${ }^{18}$ Andi Ahmad Lubis, Op. Cit., hlm. 219
} 
elektronik terpadu, dan rahasia dagang, serta perjanjian yang berkaitan dengan waralaba.

Hak atas kekayaan intelektual atau juga dikenal dengan HKI merupakan terjemahan atas istilah Intelectual Property Right (IPR). Istilah tersebut terdiri dari tiga kata kunci, yaitu hak, kekayaan, dan intelektual. Kekayaan merupakan abstraksi yang dapat dimiliki, dialihkan, dibeli, maupun dijual. Adapun kekayaan intelektual merupakan kekayaan atas segala hasil produksi kecerdasan daya pikir seperti teknologi, pengetahuan, seni, sastra, gubahan lagu, karya tulis, karikatur, dan seterusnya. Terakhir, hak atas kekayaan intelektual (HKI) merupakan hak-hak (wewenang/kekuasaan) untuk berbuat sesuatu atas kekayaan intelektual tersebut, yang diatur oleh norma-norma atau hukum-hukum yang berlaku. ${ }^{19}$

Awalnya, istilah hak milik intelektual merupakan padanan kata terhadap istilah Intelectual Property Rights, sebagaimana terdapat di dalam Garis-Garis Besar Haluan Negara Tahun 1993. Namun, para pakar hak kekayaan intelektual memperdebatkan istilah lahirnya Undang-Undang Nomor 7 Tahun 1994, maka istilah yang semula adalah hak milik intelektual sebagai padanan istilah Intelectual Property Rights diubah menjadi hak atas kekayaan intelektual atau disingkat HKI. ${ }^{20}$

Akronim HKI secara resmi digunakan dalam Undang-Undang Republik Indonesia Nomor 19 Tahun 2002 tentang Hak Cipta. Sebelumnya, para ahli seperti Sudargo Gautama dalam buku "Segi-Segi Hukum Hak Milik Intelektual" (1990) dan CST Kansil dalam buku "Hak Milik Intelektual, Hak Milik Perindustrian, dan Hak Cipta" (1997) menggunakan terminologi Hak Milik Intelektual. Istilah hak atas kekayaan intelektual digunakan oleh Bambang Kesowo dalam buku "Pengantar Umum Mengenai Hak atas Kekayaan Intelektual di Indonesia" dan disertasi di Universitas Gajah Mada Yogyakarta dengan judul "Lisensi Wajib di Bidang Hak Atas Kekayaan Intelektual (HKI) dan Prospek Penerapannya di Indonesia", $2005^{21}$

Secara normatif, HKI adalah Product of Mind atau oleh World Intelectual Property Organisation (WIPO) disebut Creation of Mind yang berarti suatu karya manusia yang lahir dengan curahan tenaga, karsa, cipta, waktu, dan biaya. Segala jerih payah itu menjadi konstribusi yang memiliki nilai ekonomi. Oleh karena itu, setiap karya intelektual patut diakui, dihargai, dan dilindungi baik secara moral dan etika maupun secara hukum. Sikap pengakuan dan penghormatan terhadap pencipta dibangun dari konsep moral dan etika, sedangkan perlindungannya difasilitasi dengan instrumen

\footnotetext{
${ }^{19}$ Adrian Sutedi, Hak Atas Kekayaan Intelektual, (Jakarta: Sinar Grafika, 2009), hlm. 38.

${ }^{20}$ Rooseno Harjowigdo, Perjanjian Lisensi Hak Cipta Musik dalam Pembuatan Rekaman, (Jakarta: Perum Percetakan Negara Republik Indonesia, 2005), hlm. 17.

${ }^{21}$ Henry Soelistyo, Hak Cipta Tanpa Hak Moral, (Jakarta: Rajawali Pers, 2011), hlm. 1.
} 
hukum. $^{22}$

Dalam Convention Estabilishing The World Intelectual Property Organization, HKI dibagi dalam dua kelompok substansi, yaitu hak cipta dan hak atas kekayaan industri. Bidang kedua mencakup paten, merek, desain industri, dan rahasia dagang. Hak cipta seringkali ditempatkan terpisah dengan hak kekayaan industri, didasarkan pada pemikiran karena bidang hak cipta yang berobjek karya seni, ilmu pengetahuan, dan karya sastra tidak ada kaitannya dengan masalah industri. Berbeda dengan paten dan merek yang mendukung serta dekat kaitannya dengan kegiatan industri. $^{23}$

Terdapat keterhubungan antara hukum persaingan usaha dengan hak atas kekayaan intelektual. Sepintas mungkin terlihat bahwa keberadaan konsepsi HKI dengan hukum persaingan usaha seakan-akan saling bertentangan satu sama lain, namun kedua domain hukum tersebut memiliki sifat komplementer atau saling mengisi untuk keharmonisan sistem hukum itu sendiri, yakni meningkatkan efisiensi sistem perekonomian. Untuk memperkuat posisi pengawasan persaingan usaha dan sebagai pintu harmonisasi antara rezim lisensi hak atas kekayaan intelektual (HKI) dan hukum persaingan usaha, ditetapkanlah Pasal 50 huruf b UU No. 5 Tahun 1999. Pada pasal tersebut dijelaskan bahwa perjanjian yang berkaitan dengan hak atas kekayaan intelektual seperti lisensi, paten, merek, hak cipta, desain produk industri, rangkaian elektronik terpadu, dan rahasia dagang serta perjanjian yang berkaitan dengan waralaba dikecualikan dari ketentuan UU No. 5 Tahun 1999.

HKI merupakan insentif dan alasan diberikan hak memonopoli dan proteksi karena HKI membutuhkan sumber daya dan waktu dalam mendapatkannya. UU HKI sendiri menjamin bahwa penemuan paten dan lain-lain akan diberikan perlindungan sebelum dapat menjadi milik publik (public domain). Faktor ini menjadi penentu bagi perusahaan karena insentif ini dianggap sebagai jalan menguasai pasar tetapi tidak merupakan pelanggaran undang-undang. Sejauh ini, negara dan hukum telah memberikan hak istimewa yang besar kepada pemegang HKI. Namun banyak orang yang salah kaprah, menyangka bahwa lahirnya hak ekslusif dalam lingkup HKI seolah-olah secara otomatis melahirkan pula praktek monopoli dan perilaku persaingan usaha tidak sehat. Padahal, seharusnya keberadaan hak ekslusif tersebut dipisahkan terlebih dahulu dari tindakan pengeksploitasiannya. Hak ekslusif hanya memberikan landasan hukum untuk memonopoli, tetapi sifatnya fakultatif atau optional. Artinya, jika pemegang HKI memutuskan untuk tidak mengeksploitasi secara komersial

\footnotetext{
${ }^{22}$ Ibid., hlm. 2.

${ }^{23}$ Ibid., hlm. 3.
} 
ciptaannya, misalnya memberikan share-alike license, maka tidak akan terjadi suatu kondisi persaingan usaha tidak sehat.

Hukum HKI mengatur tentang apa saja yang dapat dilakukan oleh pemegang HKI dalam suatu kegiatan perekonomian. Sedangkan, hukum persaingan usaha mengatur tentang batasan-batasan agar pemegang HKI dalam menjalankan kegiatan usahanya tidak menimbulkan persaingan usaha tidak sehat. Oleh karena itu pemegang HKI diharap mampu menjaga persaingan usaha secara sehat.

Dapat disimpulkan bahwa hukum HKI dan hukum persaingan usaha dianggap sebagai ketentuan hukum yang bersifat komplementer atau saling mengisi untuk keharmonisan sistem hukum nasional Indonesia. Kesamaan yang dimiliki oleh kedua rezim hukum tersebut diantaranya ialah pada tujuannya, yaitu untuk memajukan sistem perekonomian nasional di era perdagangan bebas dan globalisasi, mendorong inovasi dan kreatifitas serta untuk meningkatkan kesejahteraan rakyat. Walaupun pada kenyataannya HKI dapat memberikan hak eksklusifitas sebagai insentif dari penemuan HKI tersebut.

\section{Pengaturan Pengecualian Perjanjian Hak Kekayaan Intelektual dalam Hukum Persaingan Usaha}

Perjanjian sebagaimana diatur dalam definisi yang dirumuskan pada Pasal 1 angka 7 diartikan sama dengan perbuatan, artinya perjanjian yang dilakukan oleh pelaku usaha. Dalam hukum persaingan, hak kekayaan intelektual (HKI) maupun waralaba sering dianggap bersifat paradoks karena memberikan hak untuk memonopoli secara ekslusif yang bahkan dilindungi oleh undang-undang. Sementara itu, UU Persaingan Usaha berupaya mengatur agar monopoli yang diizinkan haruslah seimbang dan tidak dieksploitasi.

Pada dasarnya adalah, HKI bertujuan untuk peningkatan kualitas kehidupan manusia dan untuk mendapatkannya harus melalui penelitian, waktu dan biaya yang tidak murah. Sehingga wajar untuk memberikan intensif untuk menikmati hasil temuannya dan mendapatkan keuntungan secara ekonomi melalui pemberian monopoli dalam kurun waktu tertentu sebelum menjadi milik publik (public domain). Pada intinya, HKI mengatur tentang penghargaan atas karya orang lain yang berguna bagi masyarakat banyak. Ini merupakan titik awal dari pengembangan lingkungan yang kondusif untuk pengembangan inovasi, kreasi, desain dan berbagai bentuk karya intelektual lainnya. HKI bersifat privat, namun hanya akan bermakna jika diwujudkan dalam bentuk produk di pasaran, digunakan dalam siklus permintaan, penawaran, dan sesudahnya barulah akan berperan penting 
dalam ekonomi yang memberikan insentif kepada pelaku usaha yang mewujudkannya untuk menikmati hasilnya. ${ }^{24}$

HKI sering menjadi topik yang kontroversial dalam hukum persaingan usaha karena hak monopoli yang diberikannya adalah legal sesuai dengan ketentuan undang-undang. HKI memberikan beberapa nilai ekonomi pada pemilik atau penemunya yaitu: ${ }^{25}$

a. sebagai hak milik yang bersifat alamiah atau natural;

b. sebagai insentif di mana penemu atau pemilik berhak menerima kompensasi sebagai keberhasilan usaha mereka yang menguntungkan konsumen; dan

c. sebagai kelanjutan insentif di mana penemu atau pemilik akan terus melakukan penemuan atau peningkatan terhadap temuan awalnya.

HKI merupakan benda yang bersifat tidak berwujud sehingga perlu mendapat perlindungan hukum, kalau tidak maka penumpang gelap (free rider) akan menggunakan kesempatan untuk menikmati hasil temuannya tanpa perlu mengeluarkan biaya. Oleh sebab itu, pencegahan dapat dilakukan dengan jalan: ${ }^{26}$

a. memberikan hak yang dilakukan oleh pemerintah maupun peraturan perundang-undangan; dan

b. menjamin hal para penemu untuk melindungi penemuannya, kebebasan untuk menjual, menyewakan temuan atau haknya termasuk menikmati keuntungan yang bersifat ekslusif.

\section{a. Ruang Lingkup Pengaturan}

Pengecualian berdasarkan Pasal $50 \mathrm{~b}$ UU Persaingan Usaha tersebut dijabarkan Komisi Pengawas Persaingan Usaha (KPPU) dengan mengeluarkan Peraturan Komisi Pengawas Persaingan Usaha Nomor 2 Tahun 2009 tentang Pengecualian Penerapan UU No. 5 Tahun 1999 tentang Larangan Praktek Monopoli dan Persaingan Usaha Tidak Sehat Terhadap Perjanjian yang Berkaitan Dengan Hak Atas Kekayaan Intelektual

Ruang lingkup pengaturan berdasarkan PerKom Nomor 2 Tahun 2009 adalah: ${ }^{27}$ (1) perjanjian lisensi yang berada dalam lingkup hak paten, hak merek, hak cipta, hak desain industri, hak desain tata letak sirkuit terpadu,

${ }^{24}$ Zen Umar Purba, Peta Mutakhir Hak Kekayaan Intelektual Indonesia, (Departemen Kehakiman dan Hak Azasi Manusia: Direktorat Jenderal Hak Kekayaan Intelektual, 2000), hlm. 1.

${ }^{25}$ Andi Ahmad Lubis, Op. Cit., hlm. 235.

${ }^{26}$ Ibid.

${ }^{27}$ Pedoman Pelaksanaan Ketentuan Pasal 50 Huruf b tentang Pengecualian Penerapan UU No. 5 Tahun 1999 terhadap Perjanjian yang Berkaitan dengan Hak Atas Kekayaan Intelektual, hlm. 4. 
dan hak rahasia dagang. (2) merek dagang dan merek jasa. (3) desain tata letak sirkuit terpadu.

Perjanjian lisensi ${ }^{28}$ adalah perjanjian antara dua pihak atau lebih, yang mana satu pihak yaitu pemegang hak bertindak sebagai pihak yang memberikan lisensi, sedangkan pihak yang lain bertindak sebagai pihak yang menerima lisensi. Pengertian lisensi itu sendiri adalah izin untuk menikmati manfaat ekonomi dari suatu obyek yang dilindungi HKI untuk jangka waktu tertentu. Sebagai imbalan atas pemberian lisensi tersebut, penerima lisensi wajib membayar royalti dalam jumlah tertentu dan untuk jangka waktu tertentu. Mengingat hak ekonomis yang terkandung dalam setiap hak eksklusif adalah banyak macamnya, maka perjanjian lisensi pun dapat memiliki banyak variasi. Ada perjanjian lisensi yang memberikan izin kepada penerima lisensi untuk menikmati seluruh hak eksklusif yang ada, tetapi ada pula perjanjian lisensi yang hanya memberikan izin untuk sebagian hak eksklusif saja, misalnya lisensi untuk produksi saja, atau lisensi untuk penjualan saja.

Dalam konteks tersebut maka langkah-langkah yang dilakukan untuk menganalisis apakah suatu perjanjian lisensi merupakan pengecualian yang dikecualikan adalah sebagai berikut: ${ }^{29}$

1) pertama, sebelum diperiksa lebih lanjut perlu diperjelas mengenai hal yang akan dianalisa mengenai kemungkinan penerapan pengecualian Pasal 50 huruf b. Apabila yang menjadi masalah ialah penolakan untuk memberikan lisensi dan bukan lisensi itu sendiri maka perlu dianalisa HKI yang dimintakan lisensinya dapat dikategorikan merupakan prasarana yang sangat penting (essential facilities). Apabila tidak termasuk kategori essential facilities maka pengecualian dapat diberikan, namun sebaliknya apabila termasuk kategori essential facilities maka tidak dapat diberikan pengecualian sehingga ditindaklanjuti mengenai kemungkinan pelanggaran UU Persaingan Usaha:

2) kedua, hal yang perlu diperiksa adalah apakah perjanjian yang menjadi pokok permasalahan adalah perjanjian lisensi HKI. Apabila perjanjian tersebut bukan perjanjian lisensi HKI, maka pengecualian tidak berlaku;

3) ketiga, perlu diperiksa apakah perjanjian lisensi HKI tersebut telah memenuhi persyaratan menurut undang-undang, yaitu berupa pencatatan di Direktorat Jenderal Hak Kekayaan Intelektual. Apabila perjanjian lisensi HKI tersebut belum dicatatkan, maka pengecualian tidak berlaku; dan

4) keempat, perlu diperiksa apakah dalam perjanjian lisensi HKI tersebut terdapat klausul-klausul yang secara jelas mengandung sifat anti

\footnotetext{
${ }^{28}$ Ibid., hlm. 8 .

${ }^{29}$ Ibid., hlm. 10-11.
} 
persaingan. Apabila indikasi yang jelas tidak ditemukan, maka terhadap perjanjian lisensi HKI tersebut berlaku pengecualian dari ketentuanketentuan hukum persaingan usaha.

\section{b. Analisis Klausul Kesepakatan Ekslusif pada Perjanjian Lisensi HaKI}

Hal yang perlu dianalisis dari suatu perjanjian lisensi HKI untuk mendapat kejelasan mengenai ada tidaknya sifat anti persaingan adalah klausul yang terkait dengan kesepakatan eksklusif (exclusive dealing). ${ }^{30}$ Berdasarkan pedoman, perjanjian lisensi HKI yang dipandang mengandung unsur kesepakatan eksklusif adalah yang diantaranya mengandung klausul mengenai ${ }^{31}$ 1) Penghimpunan Lisensi (Pooling Licensing ) \& Lisensi Silang (Cross Licensing); 2) Pengikatan Produk (Tying Arrangement ); 3) Pembatasan dalam bahan baku; 4) Pembatasan dalam produksi dan penjualan; 5) Pembatasan dalam harga penjualan dan harga jual kembali; dan 6) Lisensi Kembali (Grant Back). Lebih lanjut di bawah ini diuraikan hal-hal yang perlu dipertimbangkan dalam menganalisa suatu klausul kesepakatan ekslusif, sebagai berikut:

1) Penghimpunan Lisensi (Pooling Licensing) dan Lisensi Silang (Cross Licensing $)^{32}$

Penghimpunan Lisensi (Pooling Licensing) merupakan tindakan para pelaku usaha untuk saling bekerjasama dengan para mitra usahanya untuk menghimpun lisensi HKI terkait komponen produk tertentu. Sedangkan, Lisensi Silang (Cross Licensing) merupakan tindakan saling melisensikan HKI antar para pelaku usaha dengan mitranya, biasanya hal tersebut dilakukan dalam kegiatan R\&D. Dengan melakukan Penghimpunan Lisensi dan/atau Lisensi Silang para pelaku usaha dapat mengurangi biaya transaksi (transaction cost) hak eksklusif yang akhirnya membuat produk dihasilkan menjadi lebih murah.

Dalam menganalisis apakah klausul mengenai penghimpunan lisensi dan lisensi silang bersifat anti persaingan usaha atau tidak, maka setiap pihak hendaknya memandang bahwa pemberi lisensi (licensor) pada prinsipnya dapat melakukan penghimpunan lisensi dan lisensi silang untuk mengefisiensikan kegiatan usahanya. Namun demikian, apabila dari tindakan tersebut membuat produksi atau pemasaran terhadap suatu produk dikuasai secara dominan oleh suatu pelaku usaha, sehingga pelaku usaha lain sulit

${ }^{30}$ Ningrum Natasya Sirait, dkk., Ikhtisiar Ketentuan Hukum Persaingan Usaha, (Jakarta: The Indonesia Netherlands National Legal Reform Program, 2010), hlm. 198.

${ }^{31}$ Pedoman Pelaksanaan Ketentuan Pasal 50 Huruf b tentang Pengecualian Penerapan UU No. 5 Tahun 1999, Op. Cit., hlm. 11.

${ }^{32}$ Nigrum Natasya Sirait, Op. Cit., hlm. 199. 
untuk bersaing secara efektif, maka klausul tersebut dapat dipandang sebagai klausul yang jelas bersifat anti persaingan usaha.

\section{2) Pengikatan Produk (Tying Arrangement) ${ }^{33}$}

Dalam menganalisis apakah klausul mengenai pengikatan produk bersifat anti persaingan usaha atau tidak, setiap pihak hendaknya memandang bahwa licensor pada prinsipnya dapat menggabungkan dua atau lebih produknya yang telah dilindungi HKI untuk diperdagangkan kepada masyarakat. Namun demikian, konsumen tetaplah harus diberikan pilihan untuk membeli salah satu produk saja. Oleh karena itu, klausul yang mengatur tentang penggabungan produk yang disertai dengan keharusan bagi penerima lisensi untuk menjual produk tersebut sebagai satu kesatuan kepada konsumen, sehingga konsumen tidak dapat membeli salah satu produk saja, maka dapat dipandang sebagai klausul yang jelas bersifat anti persaingan usaha.

\section{3) Pembatasan dalam Bahan Baku ${ }^{34}$}

Dalam menganalisis apakah klausul mengenai pembatasan bahan baku bersifat anti persaingan usaha atau tidak, maka setiap pihak hendaknya memandang bahwa pemberi lisensi (licensor) pada prinsipnya dapat memberikan pembatasan kepada penerima lisensi (licensee) mengenai kualitas bahan baku yang digunakan. Hal ini dipandang perlu untuk memaksimalkan fungsi teknologi, menjaga keselamatan, dan untuk mencegah bocornya rahasia. Walaupun demikian, setiap pihak pun hendaknya memahami bahwa pembatasan terhadap sumber penyedia bahan baku dapat mengakibatkan tidak adanya kebebasan bagi licensee untuk memilih kualitas bahan baku dan pemasok (supplier) bahan baku; yang akhirnya membuat pelaksanaan perjanjian lisensi tersebut tidak efisien secara ekonomi.

Selain itu, pembatasan tersebut juga dapat merugikan perusahaanperusahaan yang menyediakan bahan baku, karena menghambat akses ke pasar tersebut. Oleh karena itu, klausul dalam perjanjian lisensi yang memuat kewajiban licensee untuk menggunakan bahan baku dari sumber yang ditentukan oleh licensor secara eksklusif, padahal bahan baku serupa telah tersedia di dalam negeri dalam jumlah dan harga memadai serta dengan kualitas sama, dapat dipandang sebagai klausul yang bersifat anti persaingan usaha.

\footnotetext{
${ }^{33}$ Ibid.

${ }^{34}$ Ibid., hlm. 200.
} 
Dalam menganalisis apakah klausul mengenai pembatasan dalam proses produksi bersifat anti persaingan usaha atau tidak, setiap pihak hendaknya memandang bahwa pada prinsipnya licensor dapat memberikan pembatasan bagi licensee dalam hal proses produksi atau penjualan produk yang bersaing dengan produk milik licensor. Dalam hal pembatasan tersebut dibuat berdasarkan maksud untuk menjaga kerahasiaan know how, atau untuk mencegah penggunaan teknologi secara tidak sah, maka pembatasan tersebut dapat dianggap tidak termasuk mengganggu persaingan usaha. Tetapi, apabila pembatasan tersebut akan menghambat licensee dalam menggunakan teknologi secara efektif, maka pembatasan tersebut dapat menghilangkan para pesaing dari kesempatan dalam perdagangan. Oleh karena itu, klausul dalam perjanjian lisensi yang memuat pembatasan dalam hal proses produksi atau penjualan produk yang bersaing dengan produk milik licensor sehingga menghambat licensee dalam menggunakan teknologi secara efektif, dapat dipandang sebagai klausul yang secara jelas bersifat anti persaingan usaha.

\section{4) Pembatasan dalam Produksi dan Penjualan ${ }^{35}$}

Dalam menganalisis apakah klausul mengenai pembatasan dalam penjualan bersifat anti persaingan usaha atau tidak, setiap pihak hendaknya memandang bahwa pada prinsipnya licensor dapat menetapkan pembatasan terhadap wilayah atau jumlah produk yang diproduksi dengan menggunakan teknologi milik licensee yang boleh dipasarkan. Walaupun demikian, setiap pihak pun hendaknya memahami bahwa apabila pembatasan tersebut membuat licensee tidak dapat melakukan inovasi teknologi, maka hal tersebut dapat membuat pengembangan produk menjadi tidak efisien. Oleh karena itu, klausul dalam perjanjian lisensi yang memuat pembatasan wilayah dan jumlah produk yang dapat dipasarkan yang terbukti menghambat licensee dalam melakukan inovasi teknologi, sehingga pengembangan produk menjadi tidak efisien, dapat dipandang sebagai klausul yang jelas bersifat anti persaingan usaha.

\section{5) Pembatasan dalam Harga Penjualan dan Harga Jual Kembali ${ }^{36}$}

Dalam menganalisis apakah klausul mengenai pembatasan harga jual dan harga jual kembali bersifat anti persaingan usaha atau tidak, setiap pihak hendaknya memandang bahwa licensor dapat menentukan pada tingkat harga berapa produknya dapat dipasarkan sesuai dengan rasionalitas investasi dari produk yang bersangkutan. Walaupun demikian, setiap pihak

\footnotetext{
${ }^{35}$ Ibid., hlm. 201.

${ }^{36}$ Ibid.
} 
pun hendaknya memahami bahwa pembatasan harga tersebut dapat mengakibatkan pembatasan persaingan kegiatan bisnis antara licensee dan distributor yang akan berdampak pada berkurangnya persaingan, yang pada akhirnya hal tersebut dapat membuat pengembangan produk menjadi tidak efisien. Oleh karena itu, klausul dalam perjanjian lisensi yang memuat pembatasan harga jual dan harga jual kembali dengan cara menetapkan harga bawah, dapat dipandang sebagai klausul yang jelas bersifat anti persaingan usaha.

\section{6) Lisensi Kembali (Grant-Back $)^{37}$}

Lisensi kembali (Grant Back) merupakan salah satu ketentuan dalam suatu perjanjian lisensi di mana penerima lisensi (licensee) disyaratkan untuk selalu membuka dan menransfer informasi kepada pemberi lisensi (licensor) mengenai seluruh perbaikan dan pengembangan yang dibuat terhadap produk yang dilisensikan, termasuk didalamnya know how terkait pengembangan tersebut.

Dalam menganalisis apakah klausul mengenai lisensi kembali bersifat anti persaingan usaha atau tidak, setiap pihak hendaknya memandang bahwa tindakan ini menghalangi penerima lisensi untuk memperoleh kemajuan dalam penguasaan teknologi dan mengandung unsur ketidakadilan karena melegitimasi pemberi lisensi untuk selalu memiliki hak atas suatu karya intelektual yang tidak dihasilkannya sendiri. Oleh karena itu, klausul dalam perjanjian lisensi yang memuat kewajiban lisensi kembali (Grant Back), dapat dipandang sebagai klausul yang jelas bersifat anti persaingan usaha.

\section{Penutup}

Hukum Persaingan Usaha di negara Indonesia mengenal adanya pengecualian (exemption) untuk menegaskan bahwa suatu aturan hukum dinyatakan tidak berlaku bagi jenis pelaku tertentu ataupun perilaku/kegiatan tertentu. Undang-undang hukum persaingan usaha pada umumnya memberikan pengecualian atas dasar perjanjian, misalnya perjanjian hak kekayaan intelektual (HKI). HKI merupakan insentif dan alasan diberikan hak memonopoli dan proteksi karena HKI membutuhkan sumber daya dan waktu dalam upaya mendapatkannya. Demi memperkuat posisi pengawasan persaingan usaha dan sebagai pintu harmonisasi antara rezim lisensi hak atas kekayaan intelektual (HKI) dan hukum persaingan usaha, ditetapkanlah Pasal 50 huruf b UU No. 5 Tahun 1999. Pada pasal tersebut dijelaskan bahwa perjanjian yang berkaitan dengan hak atas kekayaan intelektual seperti lisensi, paten, merek, hak cipta, desain produk industri, rangkaian

\footnotetext{
${ }^{37}$ Ibid., hlm. 202.
} 
elektronik terpadu, dan rahasia dagang serta perjanjian yang berkaitan dengan waralaba dikecualikan dari ketentuan UU No. 5 Tahun 1999. HKI merupakan insentif dan alasan diberikan hak memonopoli dan proteksi karena HKI membutuhkan sumber daya dan waktu dalam mendapatkannya. UU HKI sendiri menjamin bahwa penemuan paten dan lain-lain akan diberikan perlindungan sebelum dapat menjadi milik publik (public domain). Faktor ini menjadi penentu bagi perusahaan karena insentif ini dianggap sebagai jalan menguasai pasar tetapi tidak merupakan pelanggaran undangundang.

\section{Daftar Pustaka}

\section{A. Buku}

At-Tariqi, Abdullah Abdul Husain, 2004, Ekonomi Islam: Prinsip Dasar dan Tujuan, Yogyakarta: Magistra Insani Press.

Bork, Robert H., 1978, The Antitrust Paradox, A Policy at War with Itself, New York: Basic Books Inc.

Brazier, Roderick Brazier dan Sianipar, Sahala, eds. 1999, "Undang-Undang Antimonopoli Indonesia dan Dampaknya Terhadap Usaha Kecil dan Menengah" The Asia Foundation.

Edwards, Corwin D., 1949, Maintaining Competition Requisites of a Governmental Policy, 1st ed, McGraw Hill Book Company, Inc .

Graham, Edward M. and Richardson, J. David, 1997, Global Competition Policy, Institute for International Economics, Washington DC.

Harjowigdo, Rooseno, 2005, Perjanjian Lisensi Hak Cipta Musik dalam Pembuatan Rekaman, Jakarta: Perum Percetakan Negara Republik Indonesia.

Hill, Hall, 2000, The Indonesian Economy Since 1966, 2nd ed. England: Cambridge University Press.

Jorde, Thomas, et all. 1996, Gilbert Law Summaries-Antitrust, 9th ed. Harcourt Brace Legal and Professional Publications. Inc.

Khemani, R.S., A Framework for the Design and Implementation of Competition Law and Policy, World Bank and OECD.

Lubis, Andi Ahmad, Dkk, 2009, Hukum Persaingan Usaha Antara Teks dan Konteks, Jakarta: Creative Media.

Purba, Zen Umar, 2000, Peta Mutakhir Hak Kekayaan Intelektual Indonesia

Direktorat Jenderal Hak Kekayaan Intelektual, Departemen Kehakiman dan Hak Azasi Manusia.

Redjeki Hatono, Sri, 2007, Hukum Ekonomi Indonesia, Malang: Bayumedia. Reksohadiprodjo, Sukanto dan Gito Sudarmo, Indriyo, 1988, Managemen Produksi, Yogyakarta: BPFE UGM. 
Rosyadi, A. Rahmad dan Ngatino, 2000, Arbitrase Islam dalam Perspektif Islam dan Hukum Positif, Bandung: PT. Citra Aditya Bakti.

Sutedi, Adrian, 2009, Hak Atas Kekayaan Intelektual, Jakarta: Sinar Grafika, Sullivan, L. A., 1977, Antitrust. Minessota: West Publishing, Co.

Soelistyo, Henry, 2011, Hak Cipta Tanpa Hak Moral, Jakarta: Rajawali Press.

Sirait, Ningrum Natasya, dkk. 2010, Ikhtisiar Ketentuan Hukum Persaingan Usaha, Jakarta: The Indonesia Netherlands National Legal Reform Program.

Wiradiputra, Ditha, Hukum Persaingan Usaha Di Indonesia, Modul, DIKTI, Jakarta 14 Desember 2004.

Yani, Ahmad dan Widjaja, Gunawan, 1999, Seri Hukum Bisnis Anti Monopoli, Jakarta: Rajawali Press. 